\section{Fernando Rodríguez}

Mansilla:

(Lima, 1979) es licenciado en Literatura Hispánica por la Pontificia Universidad Católica del Perú. Es doctor en Literatura por la Universidad de Navarra. Actualmente es profesor visitante en la Universidad de Carolina del Norte en Chape Hill (Estados Unidos). Ha publicado «Los cachorros» de Mario Vargas Llosa. Guía de lectura, en la editorial Cénlit.

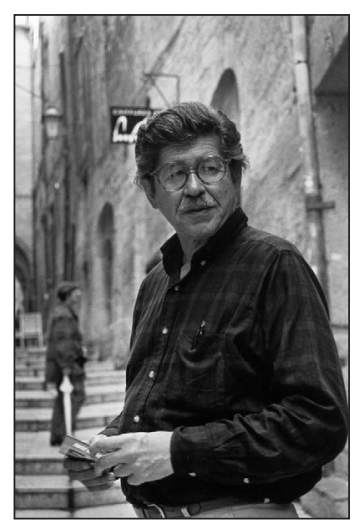

Alfredo Bryce Echenique.

1

Javier de Navascués, Los refugios de la memoria. Un estudio espacial sobre Julio Ramón Ribeyro, Madrid-Frankfurt Am Main, Iberoamericana-Vervuert, 2004 , p. 29.

2

Alfredo Bryce Echenique, "La historia personal de mis libros», en Rubén Bareiro, María Fernanda Lander y Julio Ortega (eds.), Alfredo Bryce Echenique ante la crítica, Caracas, Monte Ávila Editores Latinoamericana, 2004, p. 169

Bob López y Adán Quispe: marginales en la Lima imaginada de Ribeyro y Bryce

FERNANDO RODRÍGUEZ MANSILLA

\title{
BOB LÓPEZ Y ADÁN QUISPE:
MARGINALES EN LA LIMA IMAGINADA \\ BOB LÓPEZ Y ADÁN QUISPE:
MARGINALES EN LA LIMA IMAGINADA DE RIBEYRO Y BRYCE
}

\author{
FERNANDO RODRÍGUEZ MANSILLA
}

University of North Carolina at Chapel Hill

Este trabajo propone una reflexión sobre el tratamiento narrativo que merecen los personajes de Bob López y Adán Quispe en el relato "Alienación» de Julio Ramón Ribeyro y la novela No me esperen en abril de Alfredo Bryce Echenique, respectivamente. Ambos personajes comparten la condición de marginales en la Lima que les toca vivir y sus itinerarios guardan más de un paralelo: despreciados, frustradas sus expectativas de superación social, condenados como se sienten a desempeñar oficios bajos y mantenerse como sujetos subalternos, encuentran en el «sueño americano», el ansiado viaje a Estados Unidos, una solución, fatal, para sus dilemas existenciales. López y Quispe reiterarán su fracaso en Norteamérica y acaban muriendo en defensa de su patria adoptiva en territorios tan remotos como Corea y Vietnam. Nos interesa comparar, en especial, la función del personaje marginal en los dos textos, tanto los puntos en común como los divergentes, ya que el análisis puede arrojar algunas luces sobre la representación del subalterno como chivo expiatorio de la sociedad en el contexto de la Lima «imaginada» de los años cincuenta, es decir la ciudad generada por los textos, antes que simplemente reproducida por ellos.

No existe estudio de la narrativa urbana en el Perú que no empiece por reflexionar sobre el proceso de modernización que sufre Lima a mediados del siglo pasado. Factores como el fenómeno migratorio, la expansión de la ciudad y los cambios impulsados por el gobierno dictatorial de Manuel A. Odría han servido para identificar los nuevos intereses de los narradores que aparecen en la época. Javier de Navascués ha observado que Ribeyro, uno de los puntales de dicha generación literaria, empieza a escribir sus relatos sobre Lima en Euro$\mathrm{pa}$, por lo que, si bien posee una poética realista de estirpe decimonónica, también se alimenta de su evocación personal de la ciudad:

Parece necesario resaltar que, sin menoscabo de la importancia del interés por documentar las menudas y amargas realidades de su tiempo, también la memoria del autor debió de jugar su papel en la recreación del espacio limeño, con todo lo que de fragmentario tiene el ejercicio del recuerdo ${ }^{1}$.

Con más razón podemos hablar de la introducción de los recuerdos, por el tiempo transcurrido, en un relato como «Alienación», fechado en París en 1975. Algo similar puede afirmarse sobre No me esperen en abril, una novela cuyo gran tema, junto a los de la amistad y el amor adolescentes, es la nostalgia, la de su protagonista, Manongo Sterne, frente a una Lima que ya no existe. El propio Bryce Echenique ha declarado que No me esperen... era un proyecto que fue aplazando casi por un cuarto de siglo:

Tuvieron que pasar veinticinco años para que el personaje de esta novela [Manongo Sterne] cesara de huir de mis manos cada vez que yo quería hablar de él; veinticinco años de conversar con peruanos, veinticinco años de leer cosas, veinticinco años de ver la evolución de la sociedad peruana, para que este libro no se quedara en un conjunto de anécdotas que son las que cualquiera recuerda de su vida ${ }^{2}$. 
Esto no excluye el manto memorialista, y por tanto imaginario, que recubre la novela, pero puede darnos la clave para explicar la postura del narrador frente al personaje de Adán Quispe en la trama de No me esperen en abril, algo distinta de la del narrador del cuento ribeyreano frente a Bob López, como veremos. La lejanía geográfica de Ribeyro en los tempranos años cincuenta así como la lejanía temporal de Bryce a la hora de escribir su novela permiten ratificar una vez más el adjetivo «imaginada» para esta Lima que sus textos recrean. No hay que descartar cierto grado de influencia del autor de La palabra del mudo sobre el de Un mundo para Julius. Bryce siempre considera a Ribeyro, diez años mayor que él, «mi más grande maestro y mi amigo en aquellos años [de París]» ${ }^{3}$, por lo que los vasos comunicantes entre sus textos son una veta siempre abierta: Bob López y Adán Quispe están hermanados por su marginalidad, su obsesión por Norteamérica y sus tristes destinos.

\section{Bob López: motivo de irrisión}

«Alienación» se abre con una definición de Lima sumamente iluminadora: una «ciudad colonial» ${ }^{4}$. Como ciudad colonial, Lima posee castas y se rige por ellas. Ahora bien, siendo tal el statu quo del ambiente urbano donde se mueve Bob, este no cuenta con muchas opciones para elaborar su proyecto vital: como «zambo» debe atenerse a oficios ínfimos, propios de la plebe, como defensa del Alianza Lima (club identificado tradicionalmente con la población negra de la capital), portero o chófer. A decir de Guillermo Nugent, «los que son como López, los zambos por ejemplo, no tienen proyecto, solo pueden aspirar a un destino $»^{5}$. Frente a este destino predeterminado, nuestro personaje intenta acabar con su identidad de «zambo», que lo llama al conformismo, y volverse un "gringo», es decir un norteamericano, que a todas luces aparece, al menos en el mundo ficcional, casi como una categoría humana superior. El resultado de este proyecto es visto como algo monstruoso, un "cruce contranatura» o una «ascensión vertiginosa hacia la nada» 6 .

El proyecto de Bob López es tachado como imposible a priori por el narrador en primera personal plural, un «nosotros» que se identifica con los «blanquiñosos» ${ }^{7}$ del barrio de clase media en que vive Bob, no obstante

inferior socialmente (vive en un callejón y su madre es lavandera). El eufemismo no debe ser pasado por alto: no se trata de «blancos» propiamente dichos (como lo sería el norteamericano Billy Mulligan, el novio de Queca), a sabiendas de que todos poseen algún grado de mestizaje que les impide asumirse como racialmente puros; de allí que además de «blanquiñosos», más adelante el narrador emplee un término afín: «blancones» ${ }^{8}$. Este «nosotros», personaje-narrador colectivo, empieza adorando a Queca, una jovencita cuya familia se ubica algo por debajo de la clase media imperante en el barrio: su padre es «un empleadito que iba a trabajar en ómnibus» y su casa tenía "un solo piso y geranios en lugar de rosas» ${ }^{9}$. Luego, conforme esta va desarrollándose y madurando, se muestra muy selectiva con sus amistades, relegando a los, por así decirlo, menos blancos. Por último, va a su fiesta de promoción con Chalo Sander, blanquiñoso de colegio norteamericano, paso previo necesario para llegar a Mulligan.

La actitud de Queca es analizada por Bob, quien había sido rechazado por ella espetándole su condición racial («yo no juego con zambos» $\left.{ }^{10}\right)$. Para Bob, Queca se constituye en el mejor observatorio para estudiar cómo funciona la «ciudad colonial» que es Lima y cómo hay que proceder para superarse y escapar de la predestinación a la subalternidad. De hecho, ella es la que le da la idea de volverse norteamericano a partir del desprecio que muestra hacia los «blanquitos» y su entrega al "gringo»: hay que saltar un grado en la escala de la jerarquía racial, ya que «¿de qué le valía [a Bob] ser un blanquito más si había tantos blanquitos fanfarrones, desesperados, indolentes y vencidos?» ${ }^{11}$. Mediante esta operación, Queca «los hace sentirse [a los muchachos blanquiñosos] como si fueran una partida de zambos» ${ }^{12}$. He allí el terrible trasfondo de la historia de «Alienación»: esos muchachos que se sentín seguros de sí mismos habían aspirado hasta entonces a distinguirse mediante la competencia entre ellos para obtener el favor de la muchacha de sus sueños, la inalcanzable Queca, quien les hace ver que no son nada especiales, sino que son todos iguales ${ }^{13}$. Son tan uniformes e idénticos 3 Alfredo Bryce Echenique, «Instalar el humor en el corazón mismo de la tristeza», en Rubén Bareiro, María Fernanda Lander y Julio Ortega, op. cit., p.12.

5

Guillermo Nugent, «Apología de Bob López (lo esencial es visible a los ojos)», en Moisés Lemlij y Luis Millones (eds.), Historia, memoria y ficción, Lima, Biblioteca Peruana de Psicoanálisis, 1996, p. 145.

6 Julio Ramón Ribeyro, op. cit., p. 452.

7

Ibid., p. 453

8

Ibid., p. 458.

9

Ibid., p. 452. El detalle de los geranios en vez de rosas no ha de ser pasado por alto. En «Una medalla para Virginia» el geranio es una «flor popular» en oposición a la rosa, que se vincula con la vida burguesa; las flores operan como marca de distinción social. Javier de Navascués, op. cit., pp. 58-63.

10 Julio Ramón Ribeyro, op. cit., p. 453.

11 Ibid., p. 455

12

Guillermo Nugent, op. cit., p. 153.

13

Puesto que, como se sabe, "la causa de la violencia que históricamente corroe los cimientos de toda cultura y de todo sistema institucional, y aquello de lo cual se alimenta, a su vez, la violencia, no serán las diferencias entre los individuos de esa cultura o ese sistema, sino la profunda igualdad entre todos ellos». Cesáreo Bandera, Mímesis conflictiva. Ficción literaria y violencia en Cervantes y Calderón, Madrid, Gredos, 1975, p. 80. Justamente los muchachos blanquiñosos de "Alienación» se dedican a hacer proezas que los singularicen ante Queca: «Peluca Rodríguez se lanzó una vez de la rama más alta de un ficus, Lucas de Tramontana vino en una relu ciente moto que tenía ocho faros, el chancho Gómez le rompió la nariz a un heladero que se atrevió a silbarnos, Armando Wolff estrenó varios ternos de lanilla y hasta se puso corbata de mariposa. Pero no obtuvieron el menor favor de Queca». Julio Ramón Ribeyro, op. cit., p. 453.

Julio Ramón Ribeyro, "Alienación» en Cuentos completos, Madrid, Alfaguara, 1994, p. 452.
Bob López y Adán Quispe: marginales en la Lima imaginada de Ribeyro y Bryce

FERNANDO RODRÍGUEZ MANSILLA 
Julio Ramón Ribeyro, op. cit., p. 455 .

\section{5}

Ibid., p. 456

16

ld.

17

ld.

18

Julio Ramón Ribeyro, op. cit., p. 458.

19

Ibid., p. 459

20

Id.

21

Julio Ramón Ribeyro, op. cit., p. 460.

Bob López y Adán Quispe: marginales en la Lima imaginada de Ribeyro y Bryce

FERNANDO RODRÍGUEZ MANSILLA en relación con el singular Mulligan como lo son los zambos para los blanquiñosos. Al grupo de «nosotros» le cuesta aceptar que puede ser susceptible de discriminación: le parece en primera instancia inconcebible, ya que significa ser tratado como el zambo hijo de la lavandera.

El descubrimiento de esta verdad genera que la colectividad apele al mecanismo del chivo expiatorio. Para que no se desate el caos producto del descubrimiento de lo que consideran una afrenta (su terrible gregarismo y su inferioridad respecto del gringo) el grupo de blanquiñosos canaliza la violencia simbólica hacia el zambo Bob López, su inmediato inferior en la escala de la ciudad colonial. De allí que la historia de Queca pase a un segundo plano (aunque no se olvida) y el colectivo relegue igualmente su protagonismo para refugiarse solo en la posición de narrador. Sus objetivos quedan manifiestos tras el abandono de Queca: «Las decepciones, en general, nadie las aguanta, se echan al saco del olvido, se tergiversan sus causas, se convierten en motivo de irrisión y hasta en tema de composición literaria» ${ }^{14}$. En efecto, se han desviado las causas de la decepción: se ha pasado de discutir la elección de Queca a discutir la de Bob López. Lo que se vuelve «motivo de irrisión» ya no es la decepción provocada por el rechazo, sino el personaje del zambo que quiere convertirse en gringo. En ese aspecto, Bob sustituye a Queca como punching-ball del grupo. A su manera, ella también ha querido convertirse en gringa, no mediante la transformación física, sino mediante el vínculo matrimonial. Queca se volvería una gringa por contacto y sus hijos lo serían de pleno.

La conversión de Bob en gringo, además de retoques inútiles a su físico, pasa por un cambio en el vestido. Ya que no está en sus posibilidades traerse la ropa de Estados Unidos, la compra en remates de norteamericanos que se van del Perú ${ }^{15}$. Al señalar el narrador que Bob viste ropa usada, resalta una identidad también de segunda mano, artificial. Bob empieza a sufrir la crítica de la gente al pretender ser lo que no es, por negar su identidad convencionalmente inferior. El parecer de su jefe, Cahuide Morales, «mestizo huatón, ceñudo y regionalista» ${ }^{16}$, una suerte de encarnación de la conciencia nacional, es contundente sobre las pretensiones de Bob: «Nada [a Cahuide Morales] lo reventaba más que no ser lo que uno era. Cholo o blanco era lo de menos, lo importante era la mosca, el agua, el molido, conocía miles de palabras para designar la plata» ${ }^{17}$. Morales aplica la máxima de que el dinero 'blanquea' y encubre cualquier rasgo étnico por más incómodo que sea. Por ello, al no querer entender esta máxima vital, la salida de Bob de la pastelería que Morales regenta resulta ser un preludio de su expulsión del país.

Ante este panorama de incomprensión total hacia su proyecto, Bob, ahora con su cómplice José María Cabanillas (otro zambo como él), se refugia en un espacio utópico levantado entre cuatro paredes: con música e imágenes tópicas (Frank Sinatra y fotografías de Nueva York), Bob tiene un Estados Unidos imaginario en su habitación, considerada «un refugio inviolable, que les permitió [a López y a Cabanillas] interpolar lo extranjero con lo nativo» ${ }^{18}$, aunque lo "nativo» son solamente ellos mismos. Resultado de su aislamiento y tesón, "nadie quería ver aquí [en Lima] con ellos» ${ }^{19}$ y por ende se sienten impulsados a escapar, ya que no pueden integrarse.

Tomada la decisión por López y Cabanillas de irse a Estados Unidos, el narrador afirma que el resto de la historia es fácil de elucubrar: «Todo lo que viene después es previsible y no hace falta mucha imaginación para completar esta parábola» ${ }^{20}$. Esta aseveración es sumamente tendenciosa y exhibe el carácter dirigido y unívoco del relato, que es considerado una "parábola», es decir una narración que pretende transmitir una verdad o enseñanza moral a través de la comparación. En este caso, el mensaje sería el de erradicar cualquier aspiración a erigir un proyecto similar al de Bob López, a sabiendas de lo que le puede ocurrir al iluso que lo abrace.

El narrador se regocija contando la verdad desnuda: el trato que reciben Bob y Cabanillas en Estados Unidos no es muy distinto del que merecían en el Perú. Allá son tan zambos como aquí y son tratados con el mismo desdén aplicado a los marginales. Se quiebra el mito de Norteamérica como el paraíso de la igualdad y la posibilidad de superación, a no ser mediante el enrolamiento en la milicia: «El que quisiera ir a pelear allí [a Corea] tenía todo garantizado a su regreso: nacionalidad, trabajo, seguro social, integración, medallas» ${ }^{21}$. Aquel «todo» ofrecido es lo que no poseerían jamás dos zambos en el Perú, a saber: ciudadanía y reconocimiento. 
El sentido de «parábola» para el relato culmina con la aplicación de la justicia poética a manos del narrador. Bob fracasa y muere como castigo a su intención de negarse a ser un zambo más. Cabanillas también fracasa, pero tiene la oportunidad de redimirse frente a su país, pues regresa a Lima habiéndose aceptado y asumido su identidad colonial con creces, «desempolvado ya y zambo como nunca» ${ }^{22}$, sirviendo de ejemplo acerca de las consecuencias de abrazar un objetivo tan diabólico como pretender escapar de un destino preconcebido. La conclusión aberrante a que nos induce la «parábola» en torno al final de López y el de Cabanillas no puede ser más contundente: «La premisa es, obviamente, que quien quiere ser lo que no es, por ejemplo quien emigra e inmigra, merece morir [como López], a no ser que se arrepienta [como Cabanillas]» 23 .

A continuación, tras relatar el final de la pareja de amigos, el narrador introduce un colofón que debe liquidar la "parábola» y servirle de puntillazo definitivo para demostrar los peligros de un comportamiento rebelde: como Bob, Queca también ha fracasado. Vejada por Mulligan, se marchita y es una "chola de mierda» ${ }^{24}$ en Estados Unidos, tal como lo sería también en Perú. No obstante, si analizamos la construcción del mundo narrativo ficcional en «Alienación» se descubre un detalle: el colofón a todas luces es falso, postizo. Un narrador en primera persona, como el de este relato ribeyreano, puesto que posee características humanas y no es por tanto omnisciente (como lo sería un típico narrador en tercera persona), debe justificar su conocimiento de los hechos narrados ${ }^{25}$, para lo cual debe dar a menudo testimonio de sus fuentes de información.

En efecto, a lo largo de «Alienación» el narrador se preocupa en declarar de dónde obtiene el conocimiento de la historia que nos cuenta. Inicialmente, es un narrador testigo de los actos de Bob en el barrio, durante la adolescencia. Luego, es la madre de Bob la que informa acerca de los avatares de su hijo. Así, por ejemplo: «En el callejón, decía su madre cuando venía a casa [a lavar la ropa de sus vecinos más pudientes], le habían quitado el saludo» ${ }^{26} ;$ «Su madre nos contó un día que al fin Roberto había encontrado un trabajo» ${ }^{27}$. Más adelante, cuando Bob ingresa a estudiar inglés a un instituto, son otros muchachos, seguramente conocidos del barrio, los que informan: «Quienes entonces lo vieron [en el instituto] dicen que fue el clásico chancón» ${ }^{28}$. En otras ocasiones, cuando no se cuenta con información de primera mano, el narrador hipotetiza, piensa en voz alta: «La pareja [López y Cabanillas] debía tener largas, amenísimas conversaciones» ${ }^{29}$. Se deduce que la estancia en Estados Unidos y la desaparición de Bob el narrador las recoge del relato de Cabanillas, pues este «estaba allí vivo [de regreso en Lima], contando estas historias» ${ }^{30}$. Como se ve, el narrador siempre guarda este comportamiento que le otorga condición fidedigna a todo su relato, al menos hasta llegar al colofón. ¿Cómo es posible que el narrador supiera el triste desenlace de la historia de Queca? Jamás lo declara. No hay cómo saber de dónde extrae esa información.

En el colofón el narrador se arroga, inconsistentemente, una omnisciencia que no le compete. Se trataría de su venganza final sobre la mujer que a su vez lo maltrató y que deja mucho más en ridículo al pobre Bob (su modelo, su inspiración para volverse gringo, acabó mal). Queca lleva una vida mediocre en un pueblo remoto, abrumada por la tecnología (cuenta con «todos los aparatos eléctricos inventados por la industria humana» ${ }^{31}$ ) y despreciada, ya que siempre será una «chola de mierda» ${ }^{32}$.

Hemos dicho que el narrador-personaje «nosotros» deseaba a Queca. Queca se fue con Mulligan y despreció a «nosotros». Por ello, «nosotros» tuvo que despreciar a Bob para compensar la discriminación ejercida por Queca. Con el falaz colofón el círculo se cierra, hundiendo más el miserable proyecto de vida de Bob, ratificándole post mortem que ni siquiera la linda Queca se salvó de su condición inferior en el barrio pese a que escapó al país de las oportunidades. A propósito de esto, el subtítulo de «cuento edificante seguido de breve colofón» es una fina ironía: demuestra los peligros de un modo de pensar, la «alienación» propiamente dicha que da título al relato, pero no propone una forma de superar los conflictos de identidad y marginación que personajes como Bob, Queca o Cabanillas poseen. Ése era su destino. "Así es el Perú», nos diría el narrador desde su privilegiada posesión de blanquiñoso.

Efraín Kristal ha caracterizado al narrador ribeyreano como un narrador escéptico, «siempre observando pero incapaz de com-
Wolfgang Luchting, "Sobre zambos y zambas», en Estudiando a Julio Ramón Ribeyro, Frankfurt am Main, Vervuert, 1988, p. 329.

\section{4}

Julio Ramón Ribeyro, op. cit., p. 461.

25

Lubomír Doležel, «Truth and Authenticity in Narrative», Poetics Today, 1:3 (1980), p. 18.

\section{6}

Julio Ramón Ribeyro, op. cit., p. 456.

27

lbid., p. 457

28

lbid., p. 458

29

ld.

\section{0}

Julio Ramón Ribeyro, op. cit. p. 461.

31

Id. Llama la atención que en sus Prosas apátridas aumentadas Ribeyro, quizás evocando este breve pasaje de su cuento, desarrolle mucho más la idea: «Entro a la cocina y veo a mi mujer sumergida bajo centenares de platos, tazas, fuentes, ollas, copas, cubiertos, coladores, espumaderas, aparatos eléctricos, tratando de limpiarlos y ponerlos en orden. $Y$ me digo que no hay nada peor que caer bajo la dominación de los objetos. La única manera de evitarlo es poseyendo lo menos posible. Toda adquisición es una responsabilidad y por ello una servidumbre». Julio Ramón Ribeyro, Prosas apátridas aumentadas, Lima, Milla Batres, 1978, p. 107. Mediante esta prosa apátrida, la crítica al consumismo, rasgo emblemático del capitalismo norteamericano, queda patente en aquella línea de "Alienación» y se suma a la invectiva contra Norteamérica que ejerce el narrador.

\section{2}

Julio Ramón Ribeyro, "Alienación», en Cuentos completos, Madrid, Alfaguara, 1994, p. 461.

\footnotetext{
Bob López y Adán Quispe: marginales en la Lima imaginada de Ribeyro y Bryce

FERNANDO RODRÍGUEZ MANSILLA
} 
Efraín Kristal, «El narrador en la obra de Julio Ramón Ribeyro», en Ismael Márquez y César Ferreira (eds.), Asedios a Julio Ramón Ribeyro, Lima, Fondo Editorial de la Pontificia Universidad Católica del Perú, 1996, p. 141 .

34

Hecho que va de la mano con el ingreso del capital norteamericano en la economía peruana por entonces. Como señala Cornejo Polar, «la disciplina social impuesta represivamente [por el régimen de Odría] permitió la realización de una política económica dirigida a captar inversiones norteamericanas a gran escala». Antonio Cornejo Polar, "Hipótesis sobre la narrativa peruana última», Hueso húmero, 3 (1979), p. 48. La guerra de Corea (en la que participará Bob López) es otro hito en este proceso, ya que se produce una gran demanda de materias primas, como el algodón, que será beneficiosa para la economía peruana. En No me esperen en abril uno de los mejores amigos de Manongo Sterne, el parvenu José Antonio Billinghurst Cajahuaringa, es e hijo de un hacendado algodonero de Ica enriquecido por ese boom generado por la guerra. Alfredo Bryce Echenique, No me esperen en abril, Lima, Peisa, 1995, p. 156.

35

Julio Ramón Ribeyro, op. cit., p. 455 .

\section{6}

lbid., p. 461.

37

Guillermo Nugent, op. cit., p. 147.

38

El fenómeno posee su correlato real cuando Vargas Llosa cuenta los destinos opuestos que hacia 1958 tomaron él y sus padres. Mientras el joven aspirante a novelista, todo un afrancesado, parte a Europa, con París como destino final, a realizar sus sueños de letrado, en una especie de peregrinaje bastante común para el intelectual latinoamericano desde el siglo XIX su padre, Ernesto J. Vargas, de origen humilde ly que, gracias a su espíritu emprendedor, había

Bob López y Adán Quispe: marginales en la Lima imaginada de Ribeyro y Bryce

FERNANDO RODRÍGUEZ MANSILLA

prender el mundo observado» ${ }^{33}$. En este caso, si algo ignora o no comprende el narrador de «Alienación» es el sentido de las infructuosas acciones de Bob, de Queca y de Cabanillas. ¿A qué rebelarse contra el sistema de la «ciudad colonial» que es Lima? Por otro lado, «Alienación», cuyo meollo es el rechazo de Queca hacia los «blanquiñosos», reflejaría la humillación real de un sector desplazado por un proceso de modernización que tiene a Estados Unidos como paradigma cultura ${ }^{34}$. Son estos «nuevos aires» norteamericanos los que son tan duramente criticados en el cuento: este país o su cultura no son tan maravillosos como los ingenuos de Bob, Queca o Cabanillas suponen. El contraste de estos con el personaje del chancho Gómez no debe ser pasado por alto: el blanquiñoso Gómez «se fue a estudiar a Londres» ${ }^{35}$. Además, como lo hace Nugent, aquella última línea del relato que dice «Paris, 1975»36, bien podría atribuirse también al narrador, produciendo otro fuerte contraste con los personajes de final aciago: «Por alguna razón, que en el cuento no se hace explícita, ocurren cosas desgraciadas y lamentables cuando un par de zambitos van a Nueva York o una huachafita a Kentucky, pero es algo apenas normal que un blanquiñoso [como lo sería el narrador] viaje a París» ${ }^{37}$. El narrador parece resistirse a aceptar que se está produciendo en los años cincuenta un cambio en el centro de la cultura que se irradia hacia el Perú: Europa, en el imaginario de gente común como López, Cabanillas o Queca, es desplazada por Estados Unidos ${ }^{38}$, así como el inglés empieza a ganarle terreno lentamente al francés. Esta postura reaccionaria de parte del narrador se encuentra también en la opinión de los adultos de No me esperen en abril, aunque será desatendida por los jóvenes de la misma novela.

Finalmente, las relaciones establecidas entre el colectivo de blanquiñosos (aquel «nosotros» narrador), Queca y Bob López pueden

\footnotetext{
aprendido inglés desde muy joven), se va con su madre a Estados Unidos, a Los Ángeles, para ejercer ambos labor de obreros durante más de una década y acabar como porteros y guardianes de sinagoga (Mario Vargas Llosa, El pez en el agua. Memorias, Barcelona, Seix Barral, 1993, p. 339). Dos tipos de migración radicalmente opuestos

en sus objetivos y medios: mientras el inglés es la lengua del que se va a ser obrero, el francés es la lengua del que quiere ser un intelectual.

\section{9}

Alfredo Bryce Echenique, op. cit., p. 47.

40 lbid., p. 48
}

contemplarse como un triángulo, en cuya base se encuentran los blanquiñosos y Bob López. Están al mismo nivel precisamente porque Queca, objeto del deseo, situada en lo alto, los trata como zambos. Los blanquiñosos, para Queca, son tan desdeñables como Bob. Cuando el colectivo intuye esta catástrofe, desplaza a Queca a un segundo plano y usurpa su espacio para denigrar a Bob López. Queca es destronada y reubicada en la base, junto al zambo, para que quede constancia de su inferioridad frente al grupo de los blanquiñosos.

\section{Adán Quispe: el sacrificio del inca}

No me esperen en abril tiene por protagonista a Manongo Sterne, un nostálgico que sueña con recuperar su paraíso perdido: el verano de 1953 en el Country Club y aquel abril en que empezó a estudiar en el colegio San Pablo y conoció a sus compañeros. Una vez que el colegio acaba y la relación con Teresa Mancini naufraga, Manongo se impone recuperar el pasado y fijarlo, por ello goza tanto los reencuentros que se producen cada abril. Adán Quispe es un joven inmigrante que vive en un corralón de San Isidro, cerca de la casa de Manongo, de quien se hace pronto amigo. La historia de Adán Quispe, de su proyecto vital, surca la novela de principio a fin y se entrelaza con las pretensiones de Manongo de traer de vuelta un pasado caduco.

Adán Quispe quiere irse a Estados Unidos porque ha sido rechazado por los curas alemanes, que le quiebran su sueño de ser también él un sacerdote. Sostiene Adán:

Me trataron [los curas alemanes] como a un indio de mierda, yo años estudiando y aguantándoles todo, yo sirviendo desayunos y limpiando claustros y altares $\mathrm{y}$, con las justas, si un blanquiñoso faltaba alguna mañana, me dejaban ayudar la misa, me dejaban vestirme de acólito, y el tiempo pasaba y yo cada día más beato, más estudioso, yo quería llegar a ser alguien, Manongo, quería ser como ellos, ¿por qué no?, ¿qué tienen ellos que yo no tenga?39.

Ante la discriminación, piensa que en Estados Unidos cumplirá sus sueños y encontrará la justicia divina: «Dios no existe, Manongo... [...] Y si existe, espero encontrármelo cara a cara dentro de unos añitos en Estados Unidos... Sacaré mi cinturón negro en karate y ya oirán hablar de mí en Estados Unidos» ${ }^{4}$. 
Así como para Bob López, Norteamérica es para Adán la tierra de las oportunidades, donde no será discriminado. Pero a diferencia de «Alienación», donde el narrador mostraba poco o ningún aprecio por Estados Unidos, el narrador de No me esperen en abril describe un ambiente juvenil limeño de plena simpatía por el país del Norte a través de su entrega a modelos culturales (música, películas) venidos de allá: «Pasan demasiado veloces las horas con Nat [King Cole] y Lucho [Gatica], con Pat [Boone] y Paul [Anka], con los Platters y el esfuerzo de ser como James Dean, de parecerse a Marlon Brando, de hablar golpeado, de estar Humphrey Bogart en una fiesta y no morirse en el intento» ${ }^{41}$.

Esto naturalmente no es bien visto por los padres, provenientes de la oligarquía, formados en una visión del mundo cuyo centro cultural todavía es Europa, en especial Inglaterra. El nacimiento del internado británico San Pablo, con el objeto de formar a la futura clase dirigente del Perú, obedece a este cambio percibido por los adultos, como se lo dice a Manongo su padre: «Lo que pasa es que ahora, en estos tiempos de cine norteamericano y cómics y chicles y todas esas vulgaridades... Pero, en fin, todo eso se acabó ahora [con la creación del colegio]» ${ }^{42}$. La complicidad de Manongo y Adán Quispe se comprende a partir de la admiración que ambos sienten, no obstante sus divergentes pretensiones, por la american way of life. Asimismo, el conocimiento mutuo se da gracias al hecho de que son vecinos, aunque Manongo vive en una residencia y Adán en un corralón, cuya vista entristece al primero: «Dolía todo en el corralón de Adán, pero dolía sobre todo que quedara $\tan$ cerca y tan lejos de su casa» ${ }^{43}$. Notable diferencia con los vecinos blanquiñosos de Bob López, a los que no conmovía un ápice su vida en el callejón. $Y$ es que Manongo es un idealista: siente remordimiento de ser rico sabiendo que existe gente como Adán Quispe, que es su amigo. No lo ve como otro (visión de blanquiñosos y Queca sobre López), sino como un semejante.

El sueño de Adán de ser un gringo no pasa por la transformación física, sino, a la manera de Queca, por las vías del matrimonio, del agringamiento por contacto. Pero reconoce que debe pasar por el aro del arribismo, pues tras limpiar muchas residencias, "terminaría en la residencia de la embajada norteamericana, y de ahí a Miami, de ahí a Nueva
York, de ahí a Washington D.C. hay un solo paso, Manongo, después pescas a tu gringa, triunfas en el karate, el mundo en tu bolsillo, hermano» ${ }^{44}$. Para Adán volverse gringo significa ser libre, no sumiso, alejado del comportamiento servil que debe cumplir en Lima: «Ya yo estaré en $Y U-E S-E I$ y algún dinero les mandaré [a los de su familia] pero que se queden ahí [en el corralón] por ignorantes, por obedientes, por no saber mandar a la mierda a unos curas como los de San Felipe»45.

La visión pesimista de Adán Quispe sobre sus congéneres venidos de la Sierra no se cumplirá del todo, según lo atestigua el paso de las décadas en No me esperen en abril. Teddy Boy, el ilustre profesor del colegio San Pablo, quien tiene dotes de premonición, advertirá más tarde que «mucho cholo está invadiendo Lima y cada día hay más barriadas» ${ }^{46}$. Mucho más adelante, el narrador nos revela que Adán Quispe resulta ser el primer inmigrante andino en la capital peruana. De allí su nombre de pila. Como el Adán bíblico, el primer hombre que habitó el paraíso, Adán Quispe (cuyo apellido es el más estereotipadamente serrano, junto tal vez con «Huamán») es el primer andino que habita en Lima:

El Agustino... histórico lugar de nacimiento de las barriadas limeñas en años de prados y odrías cuarenta y cincuenta y del problema estructural migración campo-ciudad que hace llegar a Adán Quispe, una guagüita, a Lima, después a unos seis millones más como él $4^{7}$.

A continuación, el narrador resumirá todos los cambios sociales que experimenta Lima en los última mitad del siglo XX: la tugurización, el derrumbe de las izquierdas y demás partidos tradicionales, la elección de un presidente de origen japonés, la religiosidad popular encarnada en Sarita Colonia... en suma la tan manida 'cholificación' de Lima. No me esperen en abril en estas alturas adopta una perspectiva sumamente optimista de la migración, con triunfo económico incluido. El narrador recoge la voz de un inmigrante andino, cuyo discurso, el cual Cornejo Polar identificaría como inscrito en los «estereotipos puramente celebratorios» ${ }^{48}$, va en cursivas en el original:

Siete de mis bijos trabajos trabajan boy en el microtaller, monseñor, dos se dieron de baja por fiebre porcina y Dios los tenga en gloria, a la diestra de Sarita

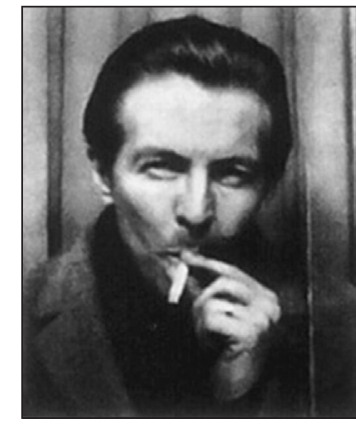

Julio Ramón Ribeyro.

41 Ibid., p. 61.

42

lbid., p. 75.

43 lbid., p. 90.

44 Ibid., p. 91.

45 Ibid., p. 93.

46

Ibid., p. 214

47 Ibid., p. 482

48

Antonio Cornejo Polar, "Una heterogeneidad no dialéctica: sujeto y discurso migrantes en el Perú Moderno», Revista Iberoamericana, 62:176-177 (1996), p. 840 .

Bob López y Adán Quispe: marginales en la Lima imaginada de Ribeyro y Bryce

FERNANDO RODRÍGUEZ MANSILLA 


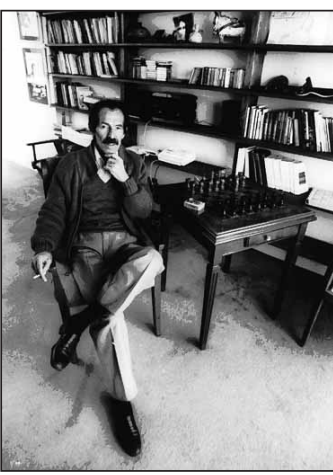

Julio Ramón Ribeyro.

\section{9}

Alfredo Bryce Echenique, op. cit., p. 489.

50

Lubomír Doležel, op. cit., pp. 16-17.

51

Ibid., p. 423.

52

Ibid., p. 476.

53

Ibid., p. 477.

54

Ibid., p. 481.

55

lbid., p. 499.

56

lbid., p. 416.
Bob López y Adán Quispe: marginales en la Lima imaginad de Ribeyro y Bryce

FERNANDO RODRÍGUEZ MANSILLA
Colonia, y los otros tres que sobrevivieron ya están programados para mandar repuestos desde Nueva Jersey, Nebraska y Orlando, y los tres últimos que be tenido naturalmente van ya al colegio y después irán a la universidad para que estudien Derecho, Contabilidad y Administración de empresas, con destino al microtaller que ya por entonces será macroexportador, si Sarita y San Martín de Porres y el Señor de los Milagros y, bueno, Dios también, para que vea que yo a usted lo respeto, señor obispo, lo permiten ${ }^{49}$.

Lo que ocurre es que el narrador en tercera persona omnisciente de No me esperen en abril a menudo asume la óptica del propio Manongo Sterne. Con este accionar, el narrador de la novela se inscribe en lo que Lubomír Doležel denomina Subjetivized Er-Form o narrador en tercera persona subjetivado. En esta modalidad se adopta, en el plano formal, la narración en tercera persona, pero en el nivel semántico se asumen las características del discurso propio de un personaje. Es el modo que adopta Gustave Flaubert en algunos pasajes de Madame Bovary, por ejemplo, cuando el narrador en tercera persona expone haciéndolos suyos los pensamientos negativos y los reproches silenciosos de Emma hacia su marido ${ }^{50}$. El narrador de No me esperen en abril ve y pondera los hechos narrados en más de una ocasión a través de los ojos de Manongo. Este, nostálgico y sentimental, impregna la narración total de la novela de todos sus afectos, sus filias y sus fobias.

Tras finalizar el colegio y al mismo tiempo romper con su amada Teresa Mancini, Manongo Sterne se vuelve un outsider, en situación afín, mas no igual, a la de su amigo Adán Quispe, quien partirá al poco tiempo a Estados Unidos a intentar cumplir sus metas. El éxito de este último como karateca, en el mundo real, parece ser inalcazable y pese a que trata de mantener contacto con Manongo, Adán Quispe acabará por esfumarse. Solo el narrador conoce y nos informa acerca del trágico final de Adán, muerto en la guerra de Vietnam al caerle por accidente una bomba lanzada por un ex alumno del San Pablo, James Alan Oxley ${ }^{51}$. Nadie en el mundo de nuestra novela llegará a saber este desenlace, con lo que el narrador propone a los lectores una relación de complicidad con él y una consecuente mirada de compasión hacia el personaje de Manongo Sterne, quien moverá cielo y tierra para encontrar a Adán Quispe.
El vacío dejado por Adán es cubierto por la ensoñación de Manongo, especialista en labrar fantasías sobre cómo querría él que fuese el mundo que lo rodea: Kid Corralón se opone a la mediocridad en la que recala Adán, malcasado y muerto en la guerra. Piensa Manongo: «Serás un ídolo, Adán. Al menos tú ganarás y campeonarás en lo tuyo: el karate» ${ }^{2}$. La invención de Kid Corralón es un acto de imaginación: «Tú ganas y yo gano contando de ti» ${ }^{53}$. Lo mismo se aplica a Teresa: «Lo que hice fue meterme en mi mundo para poderte esperar siempre ahí y fingir que la vida cotidiana también me era posible. Encontré toda una vida de sedantes en mis amigos $»^{54}$. La palabra clave aquí es mundo: «Porque de sus seres más queridos solo había perdido a Tere, pero Tere le había roto a él en pedazos un mundo entero» ${ }^{55}$. La ausencia, la imposibilidad de poseer a Teresa se subsana con el jolgorio y la inversión del orden, por ello Kid Corralón triunfa: un imposible (el éxito del chico del corralón) cubre otro imposible (el amor de Tere). El paraíso perdido por tanto involucra la recreación de la amistad transgresora de las reglas (la de un chico sanisidrino y el serrano del corralón) y el amor platónico, infecundo, inmóvil, no presencial hacia Teresa, una nueva Beatriz.

De esta forma, en No me esperen en abril se invierte el mecanismo del chivo expiatorio y se erige, por el contrario, a un (falso) ídolo que tome el lugar de la chica (la deidad auténtica) que podría darle un sentido a la existencia de Manongo. Este último no quiere admitir la realidad que se cierne sobre su idealismo, que se concentra en el éxito de su íntimo amigo y el amor de su chica. Teresa, asumiendo una postura más pragmática, le reprocha su vocación de fantasear, pero entiende a la perfección el funcionamiento de la compensación que le otorga a Manongo el invento de Kid Corralón:

Desnutrido, enano, enclenque, feo, cholo y peruanito. Dime, ¿te parece poco, Manongo? ¿Te acuerdas cuando me contaste lo del sacrificio del Inca, en el colegio? Pues imagínate al pobre Inca en Harlem, por lo menos... Imagínatelo desnutrido, enano, enclenque, feo, cholo y peruanito. ¿Realmente te parece poco?5.

Si el personaje colectivo de los blanquiñosos se ensañaba con Bob López en "Alienación» para victimizarlo, Manongo se dedica 
al enaltecimiento de Adán Quispe a sabiendas de que la realidad le da la espalda: «Tu triunfo en YU ES EI, amigo, me ayudaba a haber perdido a Tere. Pero un día Tere, Adán ya no me ayudó ni con esa esperanza [...] Adiós, cholo Adán, lo intenté todo pero dejaste del todo de escribirme y nunca mandaste fruta» ${ }^{57}$. El personaje de Adán Quispe, como el inca (versión ensalzada del sujeto andino), fue sacrificado en aras del ensueño de Manongo Sterne, permitiéndole a este no morir de amor durante un buen tiempo.

$\mathrm{La}$ experiencia de primera mano con Adán Quispe permitiría explicar igualmente la simpatía de Manongo por el general Velasco, con quien se entrevista en una de sus visitas a Lima, y reconocer como válidos sus objetivos de reivindicación social para las masas excluidas. Cuando un próspero Manongo Sterne, en los años setenta, se encuentra con la casa ruinosa donde nació el dictador, no le queda más que reflexionar: «Si yo hubiera nacido en esta casa también habría sido un resentido o, cuando menos, también habría odiado a un señor llamado Lorenzo Sterne [padre de Manongo] ${ }^{58}$. Diríase que su posición también de marginal, en razón de su personalidad soñadora y solitaria, le otorga una visión del mundo que no comparten sus amigos, encerrados en sus prejuicios oligárquicos.

Es tan fuerte la impronta de Adán Quispe en No me esperen en abril que hasta en la última fase de la vida de Manongo, cuando este pretende reconstruir el pasado invirtiendo todo su dinero para comprar réplicas del Country Club, dotando de casas enormes y apoyando económicamente a sus amigos en bancarrota, nuestro protagonista también ha contemplado en su plan maestro ubicar a Adán para comprobar que le va bien, que no fracasó en su intento: «Adam Quispe, ex Adán, tenía que ser encontrado vivo o nada ${ }^{59}$. Aunque este objetivo, como tantos otros de la utopía obstinada de nuestro protagonista, se diluye entre el marasmo y la entrega a la bebida, sin poder comprender un país que ya no se parece al que era el suyo.

Así como en "Alienación», en No me esperen en abril puede observarse un triángulo de relaciones, pero operando de manera distinta. Manongo y Adán Quispe, en la base del triángulo, son amigos y por ello se encuentran al mismo nivel. En lo alto está Teresa, cuyo abandono será paliado por Manongo median- te la idealización de la empresa de su amigo Adán. El éxito imaginario de Adán alivia el fracaso de Manongo con Tere. Cuando Adán desaparece definitivamente y la ilusión se va, la base del triángulo flaquea y se viene abajo. Por eso, Tere le ruega a Manongo, en el último capítulo de la novela, que acepte «las canas de la realidad»60. Entonces Manongo acaba por quebrarse, pues su formación, aquellos años esenciales en los que su sensibilidad y su horizonte de expectativas tomaron forma, resulta un fraude. De haber triunfado Adán, puede que la ensoñación hubiera seguido en pie o que simplemente Manongo encontrara en la auténtica amistad el mejor remedio al amor imposible.

Puestos en diálogo los textos de Ribeyro y Bryce, "Alienación» y No me esperen en abril parecen brindarnos dos visiones contrapuestas del mismo tema o dos soluciones a la función del marginal en la sociedad limeña recreada: Bob López es expulsado, es el chivo expiatorio que asegura la buena marcha del sistema de exclusión que el narrador de «Alienación» representa y exalta. Por su parte, Adán Quispe o, mejor dicho, su versión idealizada como Kid Corralón, es glorificado para revertir la derrota que el tiempo ha impuesto sobre Lima y la clase social del protagonista de No me esperen en abril. ¿A qué obedece esta notable diferencia en el tratamiento merecido por estos personajes en sus respectivos mundos ficcionales? Probablemente obedezca a la misma distancia cronológica y hasta mental, diríase, establecida entre ambos textos: ni más ni menos que veinte años (1975-1995). Mientras en el cuento de Ribeyro el marginal es un oriundo limeño, un personaje cuyo papel secundario es hasta cierto punto ancestral e institucionalizado al menos desde las Tradiciones peruanas de Ricardo Palma (piénsese en un texto como «Los aguadores de Lima»); en la novela de Bryce el marginal es un recién llegado al escenario urbano y de allí tal vez que su tratamiento literario -a sabiendas de cómo ha cambiado el país- resulte bien distinto. Cuando Ribeyro crea a Bob López está escribiendo sobre Lima a mediados del XX, pero remitiéndose a una tradición literaria cimentada desde el siglo XIX; cuando Bryce escribe sobre Adán Quispe lo hace con pleno conocimiento de los resultados que la migración del campo a la ciudad provocó. Los orígenes literarios de Bob López, así como los de la «huachafita» Queca, se encuentran en un
57

Ibid., p. 480 .

58

lbid., p. 528 .

59

Ibid., p. 543.

60

Ibid., p. 609.
Bob López y Adán Quispe: marginales en la Lima imaginada de Ribeyro y Bryce

FERNANDO RODRÍGUEZ MANSILLA 
Cf. los trabajos de Efraín Kristal, op. cit., pp. 127-148 y Antonio Cornejo Polar, «Hipótesis sobre la narrativa peruana última», Hueso húmero, 3 (1979), pp. 45-64.

62

Antonio Cornejo Polar, op. cit., p. 53. rancio costumbrismo, en tanto Adán Quispe es un pioneer, un recién llegado a la geografía urbana limeña.

Otro aspecto que puede explicar la discrepancia de base entre estos narradores es el generacional. La voz narrativa de Ribeyro, surgida a inicios de los cincuenta, es la de un escéptico ${ }^{61}$, testigo de la decadencia de una cosmovisión eurocéntrica y de rasgos coloniales; Bryce, que empieza su producción una década después, se encuentra solo con ruinas y su mirada hacia la otrora 'ciudad colonial' es, ya desde entonces, algo distante. A decir de Cornejo Polar: «Esta distancia y la nitidez del corte con el pasado espléndido activa [en Bryce] una memoria irónica, crítica y nostálgica: el humor es solo la forma de suscitar con elegancia esos contenidos» ${ }^{62}$. El humor a veces ácido de Bryce, omnipresente en No me esperen en abril, le permite superar, refugiado en la ironía, la frustración que en el cuento de Ribeyro aparece como original.
Todo ello dispuesto, naturalmente, bajo la férula del recuerdo de Ribeyro y Bryce en su recreación de Lima, no obstante la sociología. No es lo mismo contemplar la sociedad peruana de mediados del siglo XX desde 1975 que hacerlo desde 1995. Son dos décadas en que la sociedad peruana ha cambiado drásticamente, en buena parte como resultado de las reformas del gobierno militar encabezado por el general Velasco (1968-1975), época en que publica Ribeyro "Alienación». Dichas reformas dieron paso a los «nuevos limeños» que serían los virtuales lectores de $N o$ me esperen en abril, publicada en mitad del gobierno de Alberto Fujimori (1990-2001). Finalmente, nos hallamos frente a dos versiones de la extinta Lima de los años cincuenta, la última más simpática que la otra (no por ello menos literaria), tal vez en razón de que sus destinatarios sean esos descendientes de Adán Quispe que se quedaron en Perú, pero lograron salir del corralón primigenio.

\footnotetext{
Bob López y Adán Quispe: marginales en la Lima imaginada de Ribeyro y Bryce
} 